\title{
CRITICAL USER FORUMS \\ - AN EFFECTIVE USER RESEARCH METHOD FOR INCLUSIVE DESIGN
}

\author{
HUA DONG and P. JOHN CLARKSON \\ Engineering Design Centre, University of Cambridge \\ JULIA CASSIM \\ Helen Hamlyn Research Centre, Royal College of Art
}

SIMEON KEATES

TJ Watson Research Center, IBM

Inclusive, or universal, design is about designing more accessible products and services for the widest possible range of users, regardless of age and capabilities. It requires better understanding and empathy with all potential users. Traditional user research methods are limited in accommodating a wide range of users and hence there is a need to find more appropriate methods of user research for inclusive design. This paper describes a method called 'Critical User Forums,' which involves direct interaction between design teams and a mixed group of users with severe disabilities. The evaluation of the effectiveness of this method for inclusive design is based on the interviews of eight UK design consultancies that took part in a design competition emphasising inclusive design and involving users, known as the DBA Design Challenge. The contribution of critical users to the DBA projects is discussed and the design teams' viewpoints on such user involvement in the process are investigated. It concludes that Critical User Forums provide an ideal chance for designers to understand a wider range of users through direct interaction with them and thus helping designers build empathy with all potential users.

\section{INTRODUCTION}

Inclusive design is defined by the UK government as a process whereby designers, manufacturers and service providers ensure that their products and services address the needs of the widest possible audience (DTI, 2000). It is used in a similar way to the term 'universal design' in the US (Preiser and Ostroff, 2001) and 'design for all' in Europe (European Institute for Design and Disability). Other concepts such as 'transgenerational design' (Pirkl, 1994) which focuses on designing to meet the needs of people from a wide range of age groups, and 'barrier-free design' (Ostroff, 2001) which focuses on removing barriers for disabled people from the built environment, are closely related to the concept of inclusive design.

The aim of inclusive design is to improve the quality of life for all by making products, environments and services more accessible and usable for the widest possible population. Inclusive design should benefit people of all ages and abilities (Centre for Universal Design, 1998). It follows the principles of user-centred design (UCD) and goes beyond UCD in that it caters for a wider population rather than ad hoc groups of users. Inclusive design actually requires empathy and understanding of all potential users. It presents a challenge to designers who usually begin the design process with some presumptions about the potential users based on their own experience and 
expectations (Norman, 1988; Cardoso et al., 2003). There is typically a lack of user involvement in the design process (Säde, 2001). At one extreme, designers tend to consider themselves as users and act out the usage process. At the other extreme real users participate in the design process. In between, designers may use their colleagues or some more relevant representatives as user models (Hasdoğan, 1996). Appropriate users are difficult to identify (Kyng, 1994) and to recruit (Norris and Wilson, 1999), and their involvement in the design process can be expensive. There is also a perception that integrating users into the process involves specialist skills from market research companies which are beyond the normal remit of product designers (Warburton, 2003). Hence, consultant designers are most likely to depend on their clients for carrying out user research. Typically clients commission market research agencies to run focus groups, where a number of representative users are gathered in one room for a discussion under the leadership of a trained moderator, and then the results are passed to designers. The problem of focus groups is apparent as designers are not involved in the process, consequently it is difficult for them to build deep understanding and empathy with the users. IDEO, a trend-leading design consultancy, has developed a number of methods on user research, for example, the Extreme User Interview (IDEO, 1994), where individuals who are extremely familiar or completely unfamiliar with the product are asked to evaluate their experience using it. It is suggested that such extreme users are often able to highlight key issues of the design problem and provide insights for design improvements (Pullin, 2003). However, identifying extreme users, interviewing them and interpreting the findings all need specialism.

Methods such as consulting haphazard users (e.g. colleagues); discussing with representative users (e.g. focus groups); or interviewing extreme users (e.g. a computer hacker), are all limited for inclusive design, as these methods do not accommodate the understanding and empathy with a wider range of users who need to be included. There is a need to find an effective way of user research for inclusive design. The next section will introduce Critical User Forums, a user research method adopted for an inclusive design competition that has a special useroriented element. The key question for the study is whether Critical User Forums are effective for inclusive design.

\section{CRITICAL USER FORUMS AND INCLUSIVE DESIGN}

Critical users in this paper refer to users with severe disabilities (motion, sensory or cognitive impairments) who can illustrate the extreme end of the usability spectrum and on whom the impact of poor design is greatest in terms of function and stigma. For example a critical user can be a blind composer who uses a CD player and a keyboard intensively, a wheelchair engineer who lives independently and uses public transportation, or an IT expert who uses his feet rather than hands to operate the computer and to drive. Such users are in a valid critical position because they have similar lifestyles, aspirations and tastes as creative designers, but have to adapt to ill thought out products that may not have been designed with consideration of their capability limitations. It was thought involving such users in the design process would help designers understand a wider user base.

Critical user forums are smaller 'focus groups' comprising four to nine critical users. The term was coined for the DBA Design Challenge, an annual inclusive design competition organised by the Small Business Programme of the Helen Hamlyn Research Centre (HHRC) and the Design Business Association (DBA). Each year, member firms of the DBA are challenged to work with critical users developing innovative scenarios for new inclusive products and services in a short period, typically six to eight weeks. To date, 21 design consultancies have participated in the DBA Design Challenge on a voluntary basis. Short-listed entrants (four to six companies each year) can get free consultancy on inclusive design and information support from the HHRC. No monetary reward but a trophy is awarded to winners. Detailed information about the DBA Design Challenge is available from the web site of HHRC and also from Cassim $(2002,2003)$ and Dong et al (2002). Critical user forums are organised at an early stage of each DBA project to push design thinking. In each case, a mixed group of critical users are 
chosen to match the scope of the project. For example, users with arthritis and vision impairments may be involved for a packaging project to illustrate problems caused by dexterity and sight losses.

The year 2000 saw four design consultancies participating in the DBA Design Challenge which focused on 'care for our future selves.' The following year five different design consultancies worked under the theme 'innovation through inclusive design.' The participant design consultancies were free to submit any proposals under broad themes such as 'working lives,' 'domestic lives,' 'urban mobility,' 'leisure and play,' 'communication,' and 'care.' Eight out of the nine design consultancies were involved in this study, and their DBA projects are listed in Table 1.

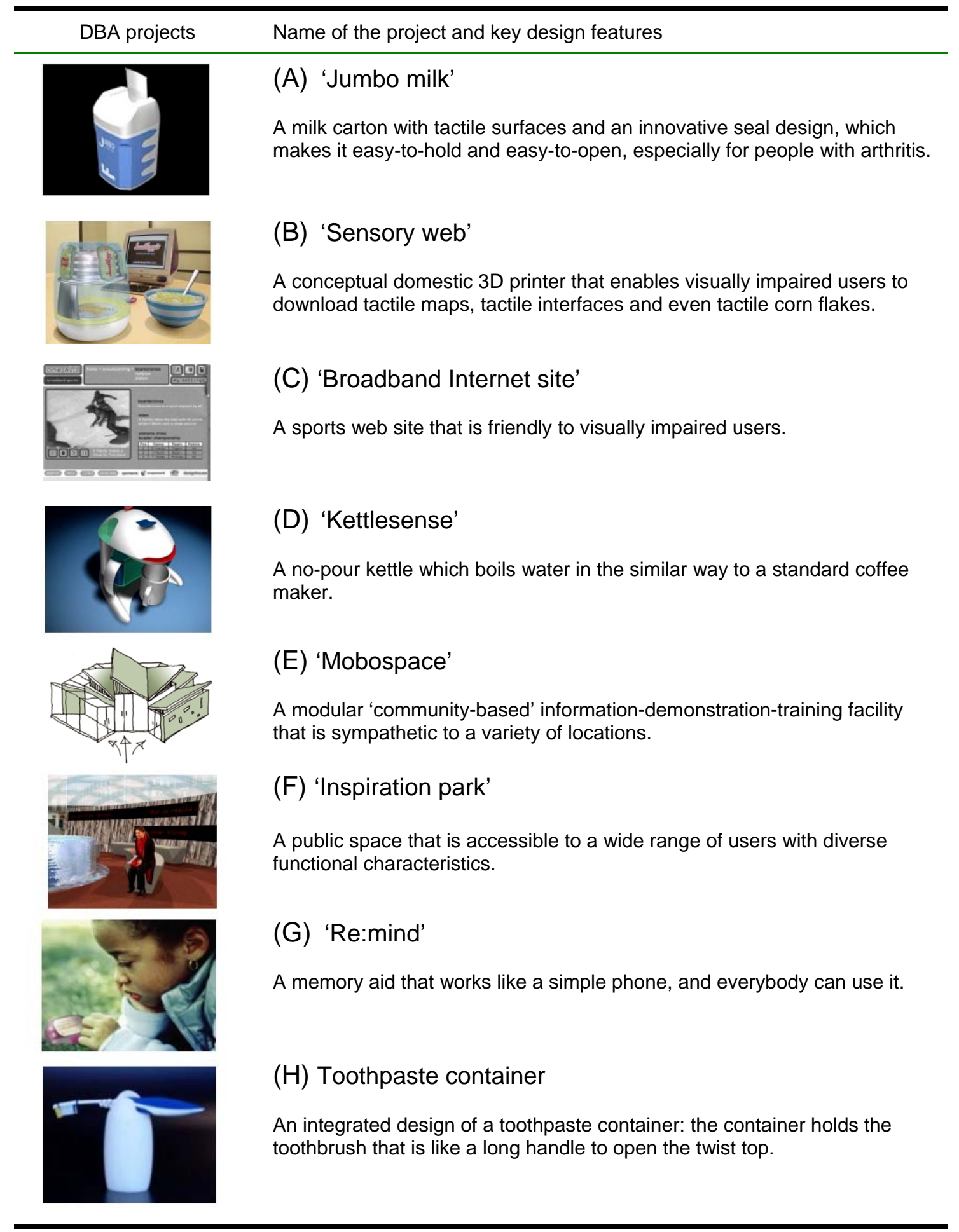

Table 1. DBA Design Challenge projects 
Critical users made contributions to all the projects listed in Table 1. Participants of the Critical User Forums were volunteers from organisations such as Arthritis Care, Different Strokes, the Foundation of Assistive Technology and the British Computer Association of the Blind. These volunteers were not paid, but the allowance for their travel costs and refreshments were provided. All the Critical User Forums took place at the HHRC. In most cases, a number of members of the design team took part in the Critical User Forums. They might bring existing products on the market and make sketches and mock-ups to illustrate their concept, and users were asked to test the products and comment on good and bad features. The design team as a whole functioned as the moderator, and all designers were free to ask questions and make enquiries to users. The atmosphere was generally informal, and the design teams were free to use various means for information capture: writing notes, observing users, making videos and taking pictures. The hands-on experience and flexible working methods enabled designers to interact with critical users effectively.

\section{CRITICAL USER FORUMS - DESIGNERS' VIEWS}

The previous section introduced the context of the study. This section is to evaluate the effectiveness of Critical User Forums for inclusive design. A series of interviews with the participant design consultancies were carried out between March and May 2002 to gain an insight into the Critical User Forums. The research hypothesis is that Critical User Forums are effective in helping designers understand potential users from a wider basis.

The interviews took place at each design consultancy, lasted on average between 90 and 120 minutes, and typically involved one to four designers and/or project managers. The interviews were performed in a structured, yet openended manner. The main questions were focused on 1) user involvement (in commercial projects and in DBA Design Challenge projects); 2) design process (including the 'normal' and the 'inclusive' design process). Designers' viewpoints on Critical User Forums were also investigated. Questions were not rigidly constrained to any certain sequences and prompts were encouraged. All the interviews were tape-recorded upon the agreement of the interviewees. Notes were also taken throughout the course of the interview. The recordings and notes were then transcribed. A full report of the interview can be found in (Dong et al, 2002), with greater details of the methodology.

The eight design consultancies provided a good representation of the design industry. Their sizes ranged from small ( 9 employees) to large (over 100 employees). Their specialist areas, the roles of the interviewees, and their conventional means of user research are summarised in Table 2.

\begin{tabular}{clll}
\hline $\begin{array}{l}\text { Design } \\
\text { consultancy }\end{array}$ & $\begin{array}{l}\text { Specialist } \\
\text { area }\end{array}$ & Interviewee(s) & Typical means of user research \\
\hline (A) & $\begin{array}{l}\text { Product, transport and } \\
\text { structural packaging } \\
\text { design }\end{array}$ & Creative director & $\begin{array}{l}\text { User trials as part of market } \\
\text { research }\end{array}$ \\
(B) & $\begin{array}{l}\text { Product, environmental } \\
\text { and transport design }\end{array}$ & Product designer & $\begin{array}{l}\text { Working with focus groups } \\
\text { organised by the client }\end{array}$ \\
(C) & $\begin{array}{l}\text { Multi-disciplinary } \\
\text { design and brand } \\
\text { strategy consultancy }\end{array}$ & $\begin{array}{l}\text { Project leader, co- } \\
\text { ordinator of web } \\
\text { site design }\end{array}$ & $\begin{array}{l}\text { Relying on external research } \\
\text { institutes or clients }\end{array}$ \\
(D) & Product design & Product director & $\begin{array}{l}\text { User trials in the middle of the } \\
\text { design process, or referring to } \\
\text { consumer reports }\end{array}$ \\
\hline
\end{tabular}




\begin{tabular}{llll}
\hline (E) & $\begin{array}{l}\text { Retail, leisure and } \\
\text { workplace design }\end{array}$ & Project leader & $\begin{array}{l}\text { In house research team which can } \\
\text { conduct questionnaire survey, } \\
\text { interviews and focus groups }\end{array}$ \\
(F) & $\begin{array}{l}\text { (Large) integrated } \\
\text { design firm }\end{array}$ & $\begin{array}{l}\text { A manager, two } \\
\text { designers, and a } \\
\text { design writer }\end{array}$ & $\begin{array}{l}\text { (Occasional) using focus groups, } \\
\text { but designers tend to play the role } \\
\text { of consumers themselves }\end{array}$ \\
(D) & Brand consultancy & $\begin{array}{l}\text { Project leader, } \\
\text { Interior designer }\end{array}$ & $\begin{array}{l}\text { Asking people around (friends or } \\
\text { relatives) for opinions and feedback }\end{array}$ \\
(H) & $\begin{array}{l}\text { Packaging and brand } \\
\text { design }\end{array}$ & $\begin{array}{l}\text { Two structural } \\
\text { designers }\end{array}$ & $\begin{array}{l}\text { Informal interviews involving } \\
\text { consumers or relying on external } \\
\text { consultancy }\end{array}$ \\
\hline
\end{tabular}

Table 2. Summary of the design consultancies

It is clear that most of these design consultancies use informal methods to obtain user information, and the majority of them tend to outsource user research. According to the design teams, the degree of user involvement in the design process is often constrained by time and budget. The interviews revealed that designers tend to be critical of focus groups. Four out of the eight design consultancies made negative comments on this, for example: 'focus groups are prone to "sheep mentality”, 'the results can be biased by dominating participants,' and 'they are "cost- and time-consuming" and "complex.",

Among the 14 interviewees, only four had previous experience of working to a design brief that required consideration of a wider range of users. For the rest of the interviewees, it is the first time for them to direct interact with disabled users. A designer said, 'I have no friends or relatives with disabilities and I can never imagine the problems these disabled users encounter in their everyday life.' However, Critical User Forums provided a chance for these designers to get to know potential users about whom they could not make assumptions based on their own experience. Table 3 gives a summary of the user involvement in the DBA projects.

\begin{tabular}{|c|c|c|}
\hline $\begin{array}{l}\text { Design } \\
\text { consultancy }\end{array}$ & $\begin{array}{l}\text { When were users } \\
\text { involved }\end{array}$ & What did users contribute to the project \\
\hline$(\mathrm{A})$ & Before concept generation & Identifying problems and user needs \\
\hline (B) & $\begin{array}{l}\text { Before and after concept } \\
\text { generation }\end{array}$ & Helping concept generation and solution development \\
\hline (C) & Before concept generation & Identifying problems and user needs \\
\hline (D) & Before concept generation & Identifying problems and user needs \\
\hline$(E)$ & After concept generation & Testing the concept and helping develop solutions \\
\hline$(F)$ & $\begin{array}{l}\text { Before and after concept } \\
\text { generation }\end{array}$ & Helping concept generation and solution development \\
\hline (G) & After concept generation & Testing the concept and helping develop solutions \\
\hline$(\mathrm{H})$ & $\begin{array}{l}\text { Before concept generation } \\
\text { (and after problem } \\
\text { analysis) }\end{array}$ & Identifying user needs \\
\hline
\end{tabular}

Table 3. User involvement in the DBA Design Challenge projects

All the Critical User Forums were organised at the early stage of the DBA project, in most cases before concept generation, and hence were used for identifying problems and user needs. Sometimes the design teams already had a concept when meeting the critical users, consequently users were consulted mainly for testing the concept and 
helping develop potential solutions. A couple of consultancies managed to contact critical users before and after concept generation - through Critical User Forums and personal contact with users, so that critical users contributed to both concept generation and solution development.

As mentioned before, another set of questions was about the design process. It was interesting to note that the designers interviewed described their 'normal' design process as a commercial process rather than a creative process. Based on the synthesis of such processes, a generic five-step model of the commercial process was developed, which reflects the fact that the client-designer relationship is emphasised, but users are ignored:

Step one: briefing (designers get the brief from the client)

Step two: finalising brief (designers interpret the brief and finalise the brief with the client)

Step three: developing concept (designers develop concepts and present them to the client)

Step four: $\quad$ selecting concept (the client selects the concept from designers' proposals)

Step five: implementing design (designers implement the final design together with the client) Although the DBA Design Challenge was not a real commercial project, all the design consultancies said they more or less had followed their 'normal' design process for this specific project (of course, there is no real client for the DBA Design Challenge). The only unique feature of the design process was user involvement. However, only two out of the eight design consultancies mentioned this difference in the interview, and the others all said the process for the DBA Design Challenge project was the same as the process for other projects. Maybe the designers were not used to count user involvement as part of the design process because their 'normal' design process did not take this factor into consideration.

When asked to comment on the Critical User Forums for the DBA Design Challenge, all design teams showed an enthusiastic appreciation of the approach. Table 4 lists typical comments from each design consultancy:

\begin{tabular}{ll}
\hline $\begin{array}{l}\text { Design } \\
\text { consultancy }\end{array}$ & Comments relevant to Critical User Forums \\
\hline
\end{tabular}

(A) 'The user forum helps us find the problem. It is an inspiring process.'

(B) 'Designers can get inspiration from critical users about how to make everyday things more accessible and interesting.'

(C) 'Meeting users with disabilities makes you think differently: you feel you are making someone's day.'

(D) 'Disabled people are expert users as they always look beyond product features to detect potential problems. They select their products thoroughly.'

(E) 'Talking to critical users is very important. It offers a fast understanding of the users. Critical users helped us to understand the headline issues.'

(F) 'Critical users can change designers' wrong perceptions and help designers work in a more organic way.'

$(G)$

'Even some common sense of the critical users is valuable to designers, as designers seldom think in that way, or they tend to ignore it.'

'Successful inclusive design depends on listening carefully to the needs and desires of others, empathising with them and remaining open-minded about the potential solutions. Things like user involvement are always helpful.'

Table 4. Comments on Critical User Forums

A designer later wrote, 'the interaction of users adds to, rather than interrupts, the flow of the design process' (Warburton, 2003). The design consultancies were specifically asked whether they would use critical users for their future projects, only one consultancy made it explicit that 'including disabled users' would be its 
consideration in the future, two design consultancies said such Critical User Forums would not be feasible for real commercial projects. Altogether four consultancies mentioned that they would prefer to consult external research institutes such as the HHRC for organising user forums if needed, including the consultancy that would consider user involvement in the future. Of the rest two consultancies, one was not sure whether it would involve end-users in the future, and the other said it did not prefer direct contact with end-users. These findings appear surprising compared with the positive feedback to the Critical User Forums in the DBA Design Challenge. This will be discussed later in the Discussion section.

The next section uses case studies to illustrate how Critical User Forums had contributed to the inclusive solutions through the DBA Design Challenge.

\section{CRITICAL USER FORUMS - ILLUSTRATION OF USE}

Two case studies are included in this section:

1. 'Kettlesense' by a smaller product design consultancy that had experience of inclusive design

2. 'Inspiration park' by a large interdisciplinary design consultancy that had no experience of inclusive design

\section{'Kettlesense'}

The design team had experience in focus groups and user trails, and these often took place after concept generation. However, for the DBA Design Challenge project, the Critical User Forum (including a user with arthritis, a blind user, a partially-sighted user and a stroke patient with the use of one-hand) was consulted before concept generation. The design team observed users' interaction with several kettles. As a result of the users' comments and suggestions, key priorities for the design consideration were identified, including:

- safety (heat of unit/boiling water);

- filling (spout size/location, water level, lid removal and replacement);

- pouring (seeing cup/tipping; weight, secure grip/low strength);

- lifting (weight, accurate water level);

- base (stability/cable management); and

- stigmatism (not for 'the disabled').

The solution was a 1-litre, aesthetically pleasing, lightweight, 'no-pour' kettle with a cool wall, audio alert, autoretractable cable, and a tactile water-level indicator (refer to Table 1).

The Creative Director of the team said, 'it is very illuminating to work with critical users.' She pointed out that 'most projects are done too quickly, and do not allow lots of focus groups. You [designers] may have one [focus group] to ensure that you are on the right track, but you do not have one at the beginning to tell what you need to do, two in the middle to ensure that you are on the right track, and one at the end to validate your solution.' She further commented on the Kettlesense project 'if we'd had enough time, we'd like to have two Critical User Forums. One for testing existing products, and the other for testing the final solution.'

\section{'Inspiration Park'}

The design team sought to provide a design concept for a public space that would 'inspire' and 'include.' The Critical User Forum (including a blind composer, a blind art student, a wheelchair-user and a user with cognitive and speech impairments) inspired the design team to introduce the following features to the 'Inspiration Park':

- a transparent roof to keep out the rain, catch the sun and yet allow rainwater to be channelled to a central fountain.

- wide, welcoming entrances; 
- a defined boundary to act as a sound barrier;

- a clear navigation system to allow safe, independent exploration;

- $\quad$ an information point and tactile maps at entrances to guide visitors; and

- $\quad$ pathways of tough compound rubber to provide a safe and comfortable surface.

One of the interviewees said, 'the aesthetics of the Inspiration Park was born from considering the usability requirements.' The design team went out to a public space with critical users and gained first-hand experience of difficulties that disabled users often encounter in an inaccessible public place. They made a film to demonstrate their solutions and obtained feedback from the critical users.

The Creative Director of the team initially considered that 'it can be difficult to use the critical user forum, especially communicating to users with speech difficulties,' later said, 'it is feasible to ask how potential users feel about the design solution. We could walk with them, or show them videos or models.' He concluded that 'after years and years of interaction with [critical] users, you may find some enthusiastic users who would like to be part of your design process. Keep their telephone numbers for contact.'

These case studies show that the Critical User Forums helped design consultancies with and without experience of inclusive design to develop an inclusive solution. However, neither consultancy envisaged that they would employ Critical User Forums for their future commercial projects, 'lack of budget and time' and 'complexity' associated with recruiting critical users were reasons given for this.

\section{DISCUSSION}

A main finding from this study is that Critical User Forums were thought useful for the DBA Design Challenge but not feasible for commercial projects. This, however, does not mean that Critical User Forums are not effective for inclusive design. On the contrary, without the contributions from the critical users, the DBA projects would not have been so successful in terms of the inclusivity of the design solutions. The insight gained from the participant design teams through the Critical User Forums for the DBA Design Challenge may well be transferred into other projects. The comments of design teams regarding Critical User Forums (Table 4) show that it is the actual interaction with a group of critical users that helps designers think in a different way. They know the products developed based on their own experience may exclude 'Mary' or 'Jack' who has certain disabilities, and they simply cannot ignore such potential exclusion any more. The impact of Critical User Forums is not limited to the DBA projects. The understanding and empathy with critical users, once built, will be embedded into the minds of designers and last for long. In this regard, Critical User Forums are an effective way of user research for inclusive design. However, the strength and weakness of the Critical User Forums must be borne in mind.

Critical User Forums are 'discounted' user research methods in that a small group of users are employed to project to a wider population. The forums are informal and do not have a fixed format. It is a fast way for designers to capture user needs and desires. Sometime designers are shocked by the difficulties that critical users have in their everyday life. The coping strategies of critical users might trigger designers' creative solutions. Younger critical users helped break the stereotypes of disabled people by demonstrating their competence in using modern technology, especially where their disabilities were sensory in nature and required alternative communication media and methods.

Critical User Forums are also a means of empowering designers and users. Designers develop their skills of working with users through practice. It was found that designers who had no experience of working with end users 
were more likely to ask general questions and make discursive comments that were not always relevant to the scope of the project - at times this did not leave enough time for key questions that should have been asked. Experienced designers would ask more specific questions and use 'laddering' skills, i.e. asking 'what,' 'how' and 'why' until they found the critical point. Users also developed their skills in evaluating design solutions and proposing alternatives.

Compared with conventional focus groups, critical users are more motivated to contribute ideas. 'Sheep mentality' is rare in critical user forms. As a designer commented, 'everybody says something, which is very good!'. Moreover, in the 'Critical user forums', designers are directly involved in the interaction with users, rather than being 'a fly on the wall,' which is typical for focus groups. However, Critical User Forums are still prone to some of the problems common to focus groups, for example dominant speakers. Communication with users having speech or hearing problems can be difficult. The selection of critical users and the associated logistics of their participation also present challenges to the organiser (Cassim and Dong, 2003). In addition, a designer pointed out that while such user forums were good for identifying practical problems and inspirational issues, they were limited in generating creative solutions.

The barriers to the adoption of Critical User Forums for commercial projects may be best countered through education to design professionals and business decision-makers. With more and more design consultancies' participating in the DBA Design Challenge, more and more businesses being aware of what is going on, the value of Critical User Forums and the benefits of inclusive design are expected to be widely recognised, and hence time and money invested on them.

\section{CONCLUSIONS AND ONGOING WORK}

'The key objective of involving [critical] users is in emphasising with their needs and desires' (Warburton, 2003). This is a typical viewpoint from designers who have participated in the DBA Design Challenge. Although most design consultancies may not be able to employ Critical User Forums for their future commercial projects due to time or financial constraints, the experience of the DBA Design Challenge has widened the designers' imagination through their interaction with critical users. This will help designers build better understanding and empathy to users for their future projects and make them aware of a wider range of users' needs and desires.

Despite the lack of experience of user research, designers' creative skills such as sketching, observation, videomaking etc prove an advantage in interacting with critical users. Some designers said, 'the interaction with critical users is not as difficult as we thought.' The informal atmosphere, the accommodation of flexible informationcapture methods, and most importantly, the direct involvement of designers (rather than market researchers or design researchers) and critical users (rather than haphazard users or able-bodied representative users), are unique features of Critical User Forums, which are in particularly appearing to creative designers.

A couple of design consultancies have taken part in the DBA Design Challenge for the second time to gain more experiences of working with critical users. The design consultancies that created Kettlesense and Jumbo milk have been seeking manufacturing partners for production. The user-friendly Broadband Internet site has been implemented and made a business case for the company. It is also known that one of the design consultancies has applied the knowledge obtained from the DBA Design Challenge to design for fire-fighters who work in a disabling environment. These facts reflect the value of Critical User Forums. 
The researchers have been involved in further studies on DBA Design Challenge 2002, 2003 and 2004, observing Critical User Forums and interviewing more design consultancies. The initial findings from these studies reinforced the main conclusion from the study of the DBA Design Challenge 2000 and 2001, i.e. Critical User Forums proves an effective user research method for inclusive design. The ongoing research also reveals that for the majority of the design consultancies participating in the DBA Design Challenge, their aims were not to pursue direct commercial application of the DBA project, but to gain the experience of working with critical users and answering an inclusive brief. Consequently the value of the DBA Design Challenge is more about raising the profile for long-term commercial successes rather than for immediate commercialisation. This somehow explains why many DBA projects from 2000 and 2001 have not been commercialised so far. The fact that more and more design consultancies are interested in participating in the DBA Design Challenge (regardless of commercial gains), indeed proves the value of Critical User Forums for inclusive design.

\section{REFERENCES}

Cardoso, C., Keates, S., and Clarkson, P.J. (2003). 'Assessment for inclusive design'. In Clarkson, P.J., Coleman, R., Keates, S., and Lebbon, C. (Eds.) Inclusive Design: Design for the Whole Population. Springer-Verlag, London, 454-474.

Cassim, J. (2002). Innovate 3. Spring 2002. Helen Hamlyn Research Centre, Royal College of Art.

Cassim, J. (2003). Innovate 5. Spring 2003. Helen Hamlyn Research Centre, Royal College of Art.

Cassim, J. and Dong, H. (2003). 'Critical users in design innovation'. In Clarkson, P.J., Coleman, R., Keates, S., and Lebbon, C. (Eds.) Inclusive Design: Design for the Whole Population. Springer-Verlag, London. 532-553.

Centre for Universal Design (1998). NC State University, School of design. USA.

At http://www.design.ncsu.edu/cud/univ_design/udhistory.htm

Dong,H., Cardoso. C, Cassim. J., Keates, S., and Clarkson, P.J. (2002). Inclusive design: Reflections on design practice. Technical report of Cambridge Engineering Department, CUED/C-EDC/TR118 - June 2002.

DTI (2000). Foresight. Department of Trade and Industry, London, UK.

European Institute for Design and Disability. At http://www.design-for-all.org/

Hasdoğan, G. (1996). 'The role of user models in product design for assessment of user needs'. Design Studies, 17, 19-33.

IDEO (1994), IDEO method cards. At: http://www.ideo.com/methodcards/MethodDeck/

Kyng, M. (1994). 'Scandinavian design: Users in product development'. Proceedings of CHI '94 Conference, ACM, Boston, USA, 3-9.

Norris, B. and Wilson, J. R. (1999). ‘Ergonomics and safety in consumer product design'. In Green, W. S. and Jordan, P.W. (Eds.) Human factors in product design - Current practice and future trends, Taylor \& Francis, London, 73-84.

Norman, D. A. (1988). The psychology of everyday things. Basic Books, New York, USA.

Ostroff, E. (2001). 'Universal design: the new paradigm'. In Preiser, W.E.F. and Ostroff, E. (Eds.) Universal Design Handbook. McGraw-Hill, New York, 1.3-1.12.

Pirkl, J. J. (1994). Transgenerational design: Products for an aging population. Van Nostrand Reinhold, New York, USA.

Preiser, W. F. E. and Ostroff, E, (2001) (Eds.). Universal Design Handbook McGraw-Hill, New York, USA. Pullin, G. (2003). 'Inclusion, inspiration and lightness of touch'. In Clarkson, P.J., Coleman, R., Keates, S., and Lebbon, C. (Eds.) Inclusive Design: Design for the Whole Population. Springer-Verlag, London, 558-564.

Säde, S. (2001). 'Towards user-centred design: method development project in a product design consultancy'. In The design journal. 4 (3), Hobbs The Printers, Totton, 20-32. 
Warburton, N. (2003). 'Everyday inclusive design'. In Clarkson, P.J., Coleman, R., Keates, S., and Lebbon, C. (Eds.) Inclusive Design: Design for the Whole Population. Springer-Verlag, London, 250-269.

\section{BIOGRAPHY}

Hua Dong studied at Tongji University in China before she joined the Engineering Design Centre in 2001 as a PhD student at University of Cambridge. She has a BE degree in industrial design and an MA degree in architectural design and theory. She is interested in product design and urban design, especially in relation to inclusive design.

Dr. P John Clarkson is Director of the Cambridge Engineering Design Centre. He spent seven years with PA Consulting Group and became Reader of University of Cambridge in 2001. His research interests include optimal design for medical devices, design for usability and the application of knowledge-based systems to complex design problems.

Much of Julia Cassim's career has been spent in Japan where she was arts columnist of The Japan Times, curated and designed award-winning exhibitions for audiences with visual impairments and learning disabilities. She joined the Helen Hamlyn Research Centre at the RCA in 1998 and runs the Small Business Programme. She received her MPhil from the International Centre for Heritage Studies at the University of Newcastle.

Dr. Simeon Keates was a Senior Research Associate in the Cambridge Engineering Design Centre. He received both his MA and $\mathrm{PhD}$ degree from the University of Cambridge. His research interests include human-computer interaction, novel input systems, user modelling and universal access. He is now working for IBM, New York.

Addresses for correspondence

Hua Dong, Dr. P John Clarkson

Cambridge Engineering Design Centre, Trumpinton Street, Cambridge CB2 1PZ, UK.

Tel: 01223766958

Emails: hd233@eng.cam.ac.uk, pjc10@eng.cam.ac.uk

http://www-edc.eng.cam.ac.uk

Julia Cassim

Royal College of Art, Kensington Gore, London SW7 2EU, UK.

Tel: 02075904242

Email: j.cassim@rca.ac.uk

http://www.hhrc.rca.ac.uk

Dr. Simeon Keates

IBM TH Watson Research Center, 19 Skyline Drive, Hawthorne, NY 10532, USA.

Tel: (914) 784-7565

Email:1sk@us.ibm.com

\section{ACKNOWLEDGEMENTS}

The authors would like to thank all the design teams for sharing their experience and Carlos Cardoso for helping with the interviews. 